\title{
Formation of Future Teachers' Motivation to Research and Experimental Activity at School
}

\author{
Nadezhda Nikolaevna Savina
}

Kazan federal university, Russia

\section{Doi:10.5901/mjss.2015.v6n6s3p59}

\section{Abstract}

\begin{abstract}
The paper considers the issue of a motivation formation of students of pedagogical specialties to professional research activity. The paper shows the data which were got as the result of doing a large-scale and a local stating experiment which preceded a forming pedagogical experiment, and also the criteria, indicators and levels of formation of students' motivation to research and experimental activity developed by the author for the efficiency assessment of the forming experiment. The author focuses her attention on three motivating factors which were especially effective in the course of formation of students' motivation to research activity. The network interaction of the higher education institution with the basic school, the system of creative (including research) tasks, the organization of the educational and research practice of students within the network interaction with school refer to them. The data which were got as the result of the forming experiment testify to good dynamics of the students' movement from the average level of a motivation formation to research activity to the high level and from the low level to the average one. It was reflected in the noticeable increase in a group of students with the high level of a motivation formation to research activity (17,48\%); the essential reduction of students entering into a group which is characterized by the low level of a motivation formation to research activity (by $22,67 \%$ ).
\end{abstract}

Keywords: motivation, research activity, teacher, school, student, experiment.

\section{Introduction}

Now many states conduct a search of ways for the professionalism increasing of school teachers on which the quality of education and, therefore, rates and the level of economics development, the social sphere of the country, its competitiveness directly depends. One of such effective ways is the training of a future teacher for professional and research activity and his inclusion in the active process of transformation of pedagogical reality. Both in Russia and abroad the research activity is considered as a kind of the activity promoting the professional growth of a teacher. So, V. I. Zagvyazinsky writes that now educational institutions have a new search and research function. Those educational institutions which will not realize it, will lose an appeal and will be not competitive. The new social situation causes a need of implementation of the research activity of an expert teacher (Zagvyazinsky V.I., 2010, p. 3-4).

M. M. Potashnik, considering the problem of management of the professional growth of a teacher, as one of the ways of its decision sees the doing pedagogical experiment. Among the forms of the professionalism increasing of teachers he also distinguishes such as departments, theoretical and scientific and practical conferences, schools of a researcher, scientific and practical laboratories, etc. (Potashnik M.M., 2009, p. 71-72; 87-90; 134-135; 153-157).

G. N. Litsman think that the research activity of a teacher promotes a training of professionally significant qualities of the personality, the increasing interest to the professional activity, the ensuring professional career (Litsman G.N., 2000, p. 77).

Foreign researchers as the considered problem note the essential influence of the research activity on the professional growth of a teacher. Ioannidou-Koutselinia M. and Patsalidoua F., for example, have the same opinion, Ioannidou-Koutselinia M. \& Patsalidoua F. (2014).

Being supporters of the cooperation between researchers and teachers, Larike H. Bronkhorst, Paulien C. Meijer, Bob Koster, Sanne F. Akkerman, Jan D. Vermunt think that it becomes more widespread and brings a benefit for the educational practice. Such cooperation promotes an acquisition by teachers of new knowledge and beliefs, leads to the new behavior of the trainee. Teachers are not passive acceptors of the interventions of researchers in the training process, they become active modifiers, adapting the interventions to local conditions (Larike H., et all, p. 91).

The researches conducted by Sardar M. Anwaruddin and Nasrin Pervin have showed that the research activity makes a deep impact on teachers who are engaged in it, and in certain cases it makes a reformative impact on classes and schools. They have established that the research activity lightens the "critical thought" of teachers, raises their self- 
assessment and awareness about pupils' needs Sardar M. Anwaruddin \& Nasrin Pervin (2015).

Despite the unanimous opinion of scientists on professional advantage of the research activity of teachers with which also teachers agree, not everyone among them shows the predisposition to this type of the professional activity. Establishing this fact, it is necessary to recognize the senselessness of presentation to a teacher of the requirement to be engaged in psychology and pedagogical research. It is known that success of any activity depends on the motivation formation to it. The formation of the conscious relation to the professional and research activity as very difficult kind of activity demanding a quite frequent overcoming of intellectual difficulties it is necessary to carry out even during a training of students in the higher education institution. Future teachers created motivation is one of the important conditions of the successful research activity in the future.

\section{Main Part}

During the development of the "Strengthening of a practical orientation of a training of future teachers in programs of a bachelor degree within the integrated group of the specialty "Education and Pedagogics" project on the direction of "Pedagogical Education" preparation (a Teacher of the main general education) on the basis of the organization of the network interaction of educational organizations realizing the programs of higher and main general education" financed by the Ministry of education and science in Russia the "Research and experimental activity of a teacher" module was developed. It included training programs as basic ("Research activity of a teacher", "Experimental work at the educational institution"), and variable ("The organization of research activity of school students", "Pedagogical diagnostics" and "Research culture and the professional growth of a teacher") subject matters, and also a program of the educational and research practice of students. The main objective of its development and approbations is formation of a teacher's readiness to the subject and author's research and the experimental pedagogical activity.

The diagnosing stage of an experiment could not be directed on the identification of levels of formation of students' readiness to the professional and research activity since none of them had no corresponding training. It assumed the development of the questionnaire for students directed on the identification of their motivation to the professional and research activity of a teacher and included:

- the study of the relation of students from different regions of Russia to the professional and research activity of a teacher of high comprehensive school

- the definition of criteria, indicators and levels of students' motivation formation to the research and experimental activity;

- the diagnostics of levels of students' motivation formation to the professional and research activity selected for a participation in the experimental-research work.

\section{Terms and Base of Doing an Experiment}

The experimental and research work on approbation of disciplines of the module was done from 22 September to 11 May 2014/15 academic years. As the basic comprehensive school participating in doing the experimental and research work MBOU SOSh "№3 of the Hero of Russia A.N. Epaneshnikov" of Elabuga of Tatarstan Republic was defined. One of its tasks was the assistance to future teacher's motivation formation to the work on all directions of the professional and research activity.

\section{Research Methods}

In the course of doind experimental and research activities (the IV level of a pedagogical experiment) on the future teachers' motivation formation to the research and experimental activity the complex of methods of the scientific and pedagogical research was used:

- the methods of the theoretical research (the study and analysis of psychology and pedagogical literature);

- the methods of the empirical research: polling (questioning, conversation): observation (direct, indirect and included supervision); the stating and forming experiment; the analysis of products of students' creative activity (an essay, questions for discussions, etc.);

- $\quad$ the methods of mathematical statistics (statistical data processing of experiment, ranging). 


\section{Participants of Experiment}

458 senior-years students of pedagogical specialties of the Elabuga institute of FGBOU VPO in the stating experiment "Kazan Federal University", FSBEI HPE "Institute of Social and Pedagogical Technologies and Resources" in Naberezhnye Chelny of Tatarstan Republic of, FSBEI HPE Tauride National University of V. I. Vernadsky in Simferopol, FSBEI HPE "Ural State Pedagogical University" in Yekaterinburg took part. Except them 70 students of the faculty of foreign languages of Elabuga Institute of Kazan Federal University who are trained at the "Pedagogical education" direction were interrogated. The same students participated in the forming experiment.

\section{The Stating Experiment}

Questioning was the main method of the research at this stage. It promoted the identification of interrogated students (four higher education institutions of three regions of Russia) of conviction that a teacher of the high comprehensive school has to be engaged in the research activity $(64,4 \%)$. $58,07 \%$ of respondents consider this direction of the professional and pedagogical activity of a teacher as the most effective way of the professional formation and the growth. To the question "If you will work at school, would you like to be engaged in the research activity?" $44,54 \%$ of students participating in questioning said "yes", negative relation to this type of the professional activity of a teacher was shown by $8,52 \%$ of examinees, $20,96 \%$ found it difficult to answer. The rest respondents $(25,98 \%)$ did not consider necessary to answer this question that it is also possible to consider as the manifestation of their relation to the professional and research activity of a teacher which is perhaps connected with the total absence by them of an information on this direction of the work of a school teacher.

Answering the question "If you plan to be engaged in the research activity at school, why?", 37,99\% of respondents reasoned their choice by a desire to work effective and modern; $21,62 \%$ of examinees plan to build career; $12,5 \%$ like to do "unknown known"; $11,79 \%$ of students think that the research activity will help them to develop the leadership skills; $9,17 \%$ of interrogated students are guided by that the research activity will help them to gain the authority of school administration; $1,09 \%$ of students consider that the research activity promotes an expansion of the outlook and updating of knowledge. $5,84 \%$ of respondents were not defined in motives of their intentions.

Ranging offered answers to the question "What, in your opinion, does induce a modern teacher to the research activity?", students on the first place put the answer "a financial interest" then "a desire to the increasing competitiveness", "an advance on the career stairs", "requirements of administration", "an internal motivation", "spirits of time", "an aspiration to increase efficiency of a teaching and educational process" followed as important for teachers (from students' point of view) and on the last place students placed "a concern about each pupil's future, a desire to provide him a professional and vital success". The latest data testify about discrepancy of senior-years students' opinions, nonformation of a future teacher's centration on interests and development of pupils' identity, immaturity of their professional and pedagogical consciousness. The data which were got allow speaking in general about the insufficient formation of future teachers of such all-professional competence as the readiness to understand the social importance of the future profession, to have a motivation to the implementation of the professional activity (The project FGOS $3+$ VO http://kpfu.ru/umu/normativnoe-obespechenie/obrazovatelnye-standarty/proekty-fgos-3.) and also, for example, such a labor action as "the systematic analysis of efficiency of studies and approaches to training" (Professionalnyi standart pedagoga, utverzhdennyi prikazom Ministerstva truda i socialnoi zashhity Rossijskoi Federatsii from «18» October 2013 № 544n., 2013).

Among the reasons interfering the professional and research activity of a teacher, students first of all specify on: 1) the lack of colleagues' moral support of; 2) the inertness of thinking; 3) the dependence on a foreign opinion; 4) the absence of special knowledge; 5) the no high professional level, etc. The first three reasons testify about no independence of future teachers, and the fourth and fifth reasons actually explain the current situation. The data received during the questioning of the great number of respondents (458 people) allow speaking about conclusions' objectivity.

For diagnostics of students' motivation formation levels to the professional and research activity selected for the participation in a pedagogical experiment (70 people) taking into account that, first, some of them had the participation experience in the research activity during a training at school; secondly, to the III year students participated in scientific and practical conferences at the higher education institution and have publications, and to the IV year they all have an experience of writing of the term paper on pedagogics or on psychology, there were defined such criteria and indicators as:

- awareness of social importance of the future profession and a role of the research activity in it (indicators: an aspiration to work effective and modern, a concern about each pupil's future and a desire to provide him a 
professional and vital success, a desire to the increasing competitiveness, $n$ aspiration to increase efficiency of a teaching and educational process";

- emotional and strong-willed (indicators: positive relation to the professional and research activity, the readiness for overcoming of intellectual difficulties, an aspiration to accumulation of professional independence in the course of the subject and author's research and experimental activity; commitment, resistance to stress, persistence, aspiration to become an intellectual leader in a pedagogical collective, etc.);

- formation of students' research position (indicators: motivational and valuable relation to the research activity; openness to an assimilation of new knowledge which are necessary for the implementation of the professional and research activity; an aspiration to the research activity and search activity; a desire to expand systematically knowledge and to gain new experience; psychological readiness for the creative activity; conviction in a need of the research activity of a teacher, an orientation to the achievement of success.

On the basis of the allocated criteria and their indicators the students' motivation formation levels to the professional and research activity were characterized. So, students who can be referred to the high level of motivation formation to the professional and research activity, are characterized by the motivated aspiration to work for a benefit of society, to the personal professional growth and increase of efficiency of their work. They are adjusted on the active professional and pedagogical activity and manifestation of the humane attitude towards pupils. Students, who can be referred to this group, seek for accumulation of professional independence and in general to success. To them the situation in a pedagogical collective is not indifferent. They are purposeful, stress-resistant and ready for overcoming intellectual difficulties, the leader ambitions are not alien to them. They consider the research activity of a teacher as means of finding of a pedagogical skill, a kind of activity in which they will be able to increase and realize both their potential and pupils' potential.

Students who have good mental abilities but do not seek for an accumulation of competitive advantages, forming the personal career, focused "just to work" can be referred to the average level of motivation formation to the professional and research activity. They differ in by that that their external motivation prevails over internal, they do not perceive the research activity of a teacher as an organic part of the teaching and educational process, see in it possibility of increase of compensation, but the activity in preparation for it do not show. The leadership skills at them are poorly created. Their strong-willed sphere becomes more active only if their personal interests are infringed. Interests of pupils make on them a weak stimulating impact.

It is impossible to claim that students belonging to the low level of motivation formation to the professional and research activity do not show predisposition to the active intellectual activity though there are also these. Among them there are a lot of intellectuals who hold an opinion that a teacher should not conduct researches (for this purpose there are scientists). Many of them are excited by the question about whether a director has the right to force a teacher to be engaged in this kind of activity. They do not show a tendency to the independent search of ways and ways for the increasing efficiency of the teaching and educational process, do not seek for mastering research competence. Some of them would like to test their strength in "other spheres of the pedagogical activity". Therefore a specially organized preparation for the professional and research and experimental activity does not cause a particular interest by them.

On "entrance" to the forming experiment all students, selected for participation in it, were held a poll (70 students). Thus the same questionnaire as for students of other Russian higher education institutions was used. As the result of processing of the obtained data it was revealed that $50 \%$ of interrogated students held an opinion that a teacher has to be engaged in the research activity at school. $31,43 \%$ of students participating in the questioning consider the professional and research activity of a teacher as the most effective way of the professional formation and the growth. To the question "If you will work at school, would you like to be engaged in the research activity?" students answered he folowing: "yes" 24,29\%; "no" - 7,14\%; "I find it difficult to answer" - 31,43\%. Other respondents $(37,14 \%)$ did not answer this question. As students selected for participation in the experiment think that to the professional and research activity of a teacher induces: 1) an advance on the career stairs; 2) a financial interest; 3) a desire to the increasing competitiveness; 4) an internal motivation; 5) an aspiration to increase efficiency of a teaching and educational process, etc. Unfortunately, students of this group point such version of the answer as "a concern about each pupil's future and a desire to provide him a professional and vital success" on the last place that points again an actual lack of a future teacher's centration on interests and development of pupils' identity.

As the result of ranging by students the reasons interfering the professional and research activity of a teacher were pointed out by them such of them as: 1) the uncertainty in itself; 2)the absence of special knowledge; 3) the lack of interest in this kind of activity; 4) the low professional level; 5) the inertness of thinking of teachers; 6 ) the laziness, etc. 
Table 1 - Students' opinion to the research activity of a teacher

\begin{tabular}{|c|l|c|c|}
\hline \multirow{2}{N}{ So } & Student's answers to the questionnaire & $\begin{array}{c}\text { Russian higher education } \\
\text { institutions (458 students) }\end{array}$ & $\begin{array}{c}\text { EI of KSU } \\
\text { (70 students) }\end{array}$ \\
\hline 1. & A teacher must be engaged in the research activity & $64,4 \%$ & $50 \%$ \\
\hline 2. & A teacher's research activity is the most effective way of a teacher's professional growth & $58,07 \%$ & $31,43 \%$ \\
\hline 3. & If I will work at school I would like to be engaged in the research activity & $44,54 \%$, & 24,29 \\
\hline 4. & I will be engaged in the research activity at school because I want to work effective and modern & $37,99 \%$ & $21,43 \%$ \\
\hline
\end{tabular}

The obtained data testify about a divergence in relation to the research activity of a teacher of students of the large higher education institutions located in big cities and students of the small higher education institution of one of the small Russian cities. It is possible to assume that a great number of students of large higher education institutions show a positive opinion to the considered direction of the professional activity of a teacher because teachers in large cities are engaged in the research activity more often, they are more often involved in large-scale experiments, take part in scientific and practical conferences, professional competitions, etc. Lower data obtained as epy result of a poll of students of El of KFU can be explained, first, by features of students' provincial mentality. Parents work for many of them at schools of the nearby small cities of Tatarstan, including at rural schools which teachers are simply not ready to the research activity and do not consider it significant for a teacher. Secondly, many students of the faculty of foreign languages participating in the questioning are trained on the additional specialty "A Translator in the Sphere of Professional Communication" and a part from them is focused on the professional activity, in particular, in a free economic zone in Elabuga of Tatarstan Republic but not at school. Perhaps, the divergence in the obtained data was affected by an essential difference in number of respondents (458 and 70). The revealed feature causes the relevance and need of a training of future teachers who are trained in small cities to the professional and research activity.

Except questioning as the main method of information collection at a stage of the organization of the experimental and research activity and also during its continuation up to its end, supervision methods, conversation and written creative works were applied (the essay, tasks of individual and group character). Application of the included supervision and free conversation promoted identification already at the initial stage of work of signs of curiosity and interest in research activity of the teacher of one group of students, a reserved position and expectation of an explanation of essence of the forthcoming work of other group of students, skeptical, time of undisguised negative attitude - the third group of students. After an explanation of essence and the content of the forthcoming experiment the attitude of students towards him was expressed even how they seated in audience. Negatively adjusted students kept together and in questions which they asked, aggressive notes sometimes sounded spiteful. But their unity to some extent did not disturb, and helped with work of the experimenter. First, it was connected with that they were brought (voluntary) together in one place and therefore a teacher's attention did not dissipate; secondly, the presence of the discordant facilitated the organization and carrying out discussions.

As the result of the stating experiment of students' motivation formation levels to the professional and research activity of a teacher were determined, namely: the high - 5,71\%; the average - 58,57\%; the lower - 35,71\%.

\section{The Forming Experiment and Its Results}

In the course of approbation of all subject matters of the "Research and Experimental Work of a Teacher" module taking into account the data obtained during the stating experiment a special attention was paid on students' motivation formation to the professional and research activity. Such methods of a training as discussion, a problem statement, methods of stimulation and motivation of a debt and responsibility in the doctrine were applied for this purpose; motivational speech; technicians "Traffic light", "Information labyrinth", "Priorities", "In the firing line" Panina T.S. \& Vavilova L.N. (2008); heuristic conversation, group exchange of opinions. Besides, the system of creative tasks assuming both individual, and group work of students was developed. It should be noted that an application of a dialogue and interactive methods of a training played a positive role in students' motivation formation to the research activity. So, they had to define quickly the position in relation to this type of the professional activity and to a lag behind it (equipment "Position"). On unmotivated or poorly motivated students a parallel impact as was made from a teacher and motivated students.

It is necessary to allocate the most effective motivating factors which made a positive impact on students' motivation formation to the professional and research and experimental activity. The first of them is the network interaction with school with which the contract on cooperation in a training of future teachers was signed. During the experiment meetings of students with a director and teachers of school were organized. They made quite strong 
impression which they expressed in writing on students. So, in reviews of visit of school they wrote the following:

- $\quad$ "having come to school, after several years of training at institute we saw that occurs at it, it is possible to tell, on the other hand. I cannot tell that I already looked at school the teacher-researcher's eyes, but saw that long time was behind a curtain as if glanced inside. We did not know that teachers are engaged in research activity therefore did not plan to be engaged in it";

- I very much liked this meeting, they are interesting and useful to us, future teachers. I would like to visit similar meetings as I plan to be engaged in research activity when I work at school", etc.

The second the effective motivating factor is the developed system creative (including, and research) tasks, assuming both individual, and group work of students.

As one more the effective motivating factor it should be noted the organization of educational and research practice of students within network interaction with school. According to its program students developed research tools (questionnaires, plans and questions for conversation, questions for interview, programs of supervision, etc. and approved them in practice at school) that caused in them positive an emotional response.

\section{Results and Conclusions}

For definition of results of experimental and research work the questionnaire and qualitative methods of scientific and pedagogical research which are not assuming statistical processing (conversation, supervision, the analysis of products of creative activity) were used. It was interesting to observe how the number of the students who are negatively adjusted in relation to research activity of the teacher was reduced. Also admissions of occupations were quickly enough reduced by them that it is possible to consider as positive shift in motivation to future professional and research activity. It should be noted that the forming experiment coincided on carrying out terms with the first work practice of students in the course of which passing they had opportunity to talk to teachers-researchers at schools and to be convinced that research activity is one of functional duties of the modern teacher now.

During purposeful work on formation at students of motivation to research activity of the teacher the data testifying to its efficiency (were obtained see: Table 2).

Table 2. Students' motivation formation levels to the research and experimental activity

\begin{tabular}{|c|c|c|c|c|}
\hline № $\Pi / \Pi$ & Level & Before the experiment & After the experiment & Efficiency indictors \\
\hline 1. & High & $5,71 \%$ & $23,19 \%$ & $+17,48 \%$ \\
\hline 2. & Average & $58,57 \%$ & $63,77 \%$ & $+5,3 \%$ \\
\hline 3. & Lower & $35,71 \%$ & $13,04 \%$ & $-22,67 \%$ \\
\hline
\end{tabular}

The obtained data testify to the noticeable increase in a group of students with the high level of motivation formation to the research activity $(+17,48 \%)$; an essential reduction of students entering into a group which is characterized by the low level of motivation formation to the research activity (for 22,67\%) and good dynamics of students' movement from the average level of motivation formation to the research activity on the high level and from the low level on the average one.

\section{References}

Zagvyazinsky, V.I. (2010) Metodologiya i metody psihologo-pedagogicheskogo issledovaniya: ucheb. posobie dlya stud. vyssh. ucheb. zavedeny / V.I. Zagvyazinsky, R.Atahanov. 6-e izd., ster. M.: Izdatelsky centr «Akademiya».

Potashnik, M.M. (2009) Upravlenie professionalnym rostom uchitelya v sovremennoi shkole. Metodicheskoe posobie. - M.: Centr pedagogicheskogo obrazovaniya.

Litsman, G.N. (2000) Nauchno-issledovatelskaya deyatelnost kak sredstvo professionalno-kvalifikatsionnogo rosta uchitelya: dis. ... kand. ped. nauk. - Ekaterinburg.

Ioannidou-Koutselinia, M. \& Patsalidoua, F. (2014). Engaging school teachers and school principals in an action research inservice development as a means of pedagogical self-awareness. Educational Action Research, http://dx.doi.org/10.1080/09650792. 2014.960531.

Larike, H. Bronkhorst, Paulien, C. Meijer, Bob Koster, Sanne, F. Akkerman \& Jan, D. Vermunt (2013). Consequential research designs in research on teacher education. Teaching and Teacher Education 33: 90-99.

Sardar, M. Anwaruddin \& Nasrin, Pervin (2015). English-language teachers' engagement with research: findings from Bangladesh, Professional Development in Education, 41:1, 21-39, DOI: 10.1080/19415257.2013.861860.

The project FGOS 3+ VO http://kpfu.ru/umu/normativnoe-obespechenie/obrazovatelnye-standarty/proekty-fgos-3.

Professionalnyi standart pedagoga, utverzhdennyi prikazom Ministerstva truda i socialnoi zashhity Rossijskoi Federatsii from «18» 
October 2013 № 544n. M.: UC Perspektiva, 2014. - 24 p. www.regulation.gov.ru.

Panina, T.S. \& Vavilova, L.N. (2008) Sovremennye sposoby aktivizatsii obucheniya: ucheb. posobie dlya stud. vyssh. ucheb. zavedeny I Edited by T.S. Panina. 4-e izd., ster. M.: Izdatelsky centr «Akademiya». 